\title{
Association between XPD Lys751Gln polymorphism and esophageal cancer susceptibility in China: a meta-analysis based on 12 case-control studies
}

\author{
Jinguo MA ${ }^{1,2,3 \#}$, Bing ZHANG ${ }^{1,2,3}$, Shuanglong ZHANG ${ }^{4}$, Zhihui GUAN ${ }^{5}$, Bin SUN ${ }^{2,3,5}$, Xiaojing $\mathrm{CHANG}^{6 \star}$
}

\begin{abstract}
Many studies have analyzed the relation about xeroderma pigmentosum group D (XPD) Lys751Gln polymorphism on esophageal cancer risk; however, the results were inconclusive. The present study was designed to assess the relationship in China. We searched the relevant articles from the databases of PubMed, Springer Link, Ovid, Chinese Wanfang Database, CNKI and Chinese Biology Medicine up to December 2019. An OR with the corresponding 95\%CI was adopted to evaluate this association. This meta-analysis included 12 studies with 4195 esophageal cancer cases and 4762 controls. Overall, a positive association between XPD Lys751Gln and esophageal cancer risk was found in all the analysis model (Gln vs. Lys, $\mathrm{OR}=1.26,95 \% \mathrm{CI}=1.14-1.44 ; \mathrm{Gln} / \mathrm{Gln}$ vs. Lys $/ \mathrm{Lys}, \mathrm{OR}=1.73,95 \% \mathrm{CI}=1.29-2.31 ; \mathrm{Gln} / \mathrm{Gln}$ vs. Lys/Lys + Asp/Asn, OR=1.63, $95 \% \mathrm{CI}=1.22-2.18 ; \mathrm{Gln} / \mathrm{Gln}+\mathrm{Asp} /$ Asn vs. Lys/Lys, $\mathrm{OR}=1.25,95 \% \mathrm{CI}=1.13-1.39)$. Subgroup analyses by geographic area and source of controls were further conducted; there was no substantial change in subgroup analyses. Our study suggested that XPD Lys751Gln polymorphism could increase the risk of esophageal cancer in China. Further studies in other ethnic populations are wanted to confirm these conclusions.
\end{abstract}

Keywords: genes; xeroderma pigmentosum group D; polymorphism; esophageal cancer; meta-analysis.

Practical Application: XPD Lys751Gln polymorphism could increase the risk of esophageal cancer in China, which promoting more detailed research on esophageal cancer.

\section{Introduction}

Esophageal cancer is the sixth most common cause of cancer death in the world. It is also the fourth most common malignancy in China (Jemal et al., 2011; Vidal et al., 2020). More and more epidemiological evidence has obvious regional characteristics. China occupied the first place of worldwide in the morbidity rate, as well as in the mortality rate of esophageal cancer. Currently, more than $50 \%$ of patients suffer from locally advanced or metastatic disease (Jemal et al., 2011; Liang et al., 2013). The mechanism of esophageal cancer pathogenesis, however, is not yet well known. Many factors contribute to the development of esophageal cancer, including alcohol intake, smoking tobacco, and micronutrient deficiency (Hongo et al., 2009). However, esophageal cancer was a complex disease. Genetic factors would be major risk factors of esophageal cancer apart from the above mentioned factors. Several common low-penetrance genes have been determinate as potential susceptibility genes of esophageal cancer. The xeroderma pigmentosum group D (XPD), as well as named excision repair cross complementing group 2 (ERCC2), is one of the eight core genes in the nucleotide-excision repair pathway (Sung et al., 1993; Boer \& Hoeijmakers, 2000). Among them, the most studied was XPD Lys751Gln polymorphism. XPD Lys751Gln is in linkage disequilibrium; meanwhile, its mutant phenotype was reported having a lower DNA repair capacity (Qiao et al., 2002). In 2002, Xing et al. (2002) firstly studied the relation about XPD Lys751Gln polymorphism on esophageal cancer risk in China. Subsequently, many articles were published to explore the relationship between them in Chinese population, with inconsistent conclusions. These different results may be caused by the studied population in different racial or regional and the small number of participants in every individual study. Thus, we designed this meta-analysis to explore more accurate association about XPD Lys751Gln polymorphism on esophageal cancer risk in China. Moreover, hierarchical analyses by geographic location and the source of controls were performed to further explore the association about XPD Lys751Gln polymorphism on esophageal cancer risk.

\section{Materials and methods}

\subsection{Articles search, inclusion criteria and data extraction}

This study was conducted following the guidelines of the PRISMA group (Moher et al., 2009). All the potential related 
articles were searched from PubMed, Springer Link, Ovid, Chinese Wanfang Database, CNKI and Chinese Biology Medicine from beginning to December 2019. The terms using in the analysis were as below: ("ERCC2" or "XPD" or "xeroderma pigmentosum group D" or "excision repair cross-complementing group 2" or "DNA repair gene") and ("esophageal" or "esophagus"). No language limitation was applied. Meanwhile, the references of retrieved articles were checked manually. We would select papers when they satisfied the following criteria: (1) case-control studies concentrating on the association about XPD Lys751Gln polymorphism on esophageal cancer risk, (2) including sufficient genetypes data which could calculate the odds ratio (OR), (3) studies reported in Chinese population, (4) human studies. The following exclusion criteria were used: (1) no sufficient data, (2) overlapped literatures, (3) case reports, editorials, reviews or abstracts. The following information was extracted from the included studies: last name of the first author, publication year, geographic location, sources of control, number of participants, and detailed genotype data with XPD Lys751Gln polymorphism. Sources of control were divided into population-based studies [PB] or hospital-based studies [HB]. Geographic areas were categorized as South China or North China.

\subsection{Statistical analysis}

OR with 95\% CI was used to analyze the influence of XPD Lys751Gln polymorphism on esophageal cancer risk under by pooling each individual odds ratios (ORs). The following comparisons were carried out: (1) allele contrast (Gln allele versus Lys allele), (2) contrast of homozygotes (Gln/Gln versus Lys/Lys), (3) recessive (Gln/Gln versus (Lys/Gln+Lys/ Lys)), and (4) dominant models ((Gln/Gln+Lys/Gln) versus Lys/Lys). The heterogeneity assumption and HardyWeinberg equilibrium (HWE) in controls were determined by chi-squarebased Q-test (Hoaglin, 2014). When the level of heterogeneity was not significant, a fixed-effect model was used for the pooled OR. Otherwise, the random-effect model was adopted. $\mathrm{Z}$ test was used to define whether the pooled OR was significant or not. Sensitivity analysis was used for compared the results between fixed-effects model and random-effects model. Publication bias was estimated by Begg's funnel plot and Egger's linear regression test. All the analyses were performed under the Stata version 12 (StataCorp LP, College Station, TX). A $\mathrm{P}<0.05$ indicated a significant difference. Moreover, hierarchical analyses with geographic location and sources of control were further done.

\section{Results}

\subsection{Research characteristics}

Eighty articles which assessed the relationship about XPD polymorphisms on esophageal cancer risk were identified. At last, twelve studies met the above mentioned criteria and 68 articles were excluded. All the eligible articles were published from 2002 to 2014 . The flow chart was present in Figure 1. Totally, there were 4195 esophageal cancer cases and 4762 controls applied to the current meta-analysis, which assessed the association of XPD Lys751Gln polymorphism and esophageal cancer risk in Chinese. The characteristics of all suitable studies were shown in Table 1.

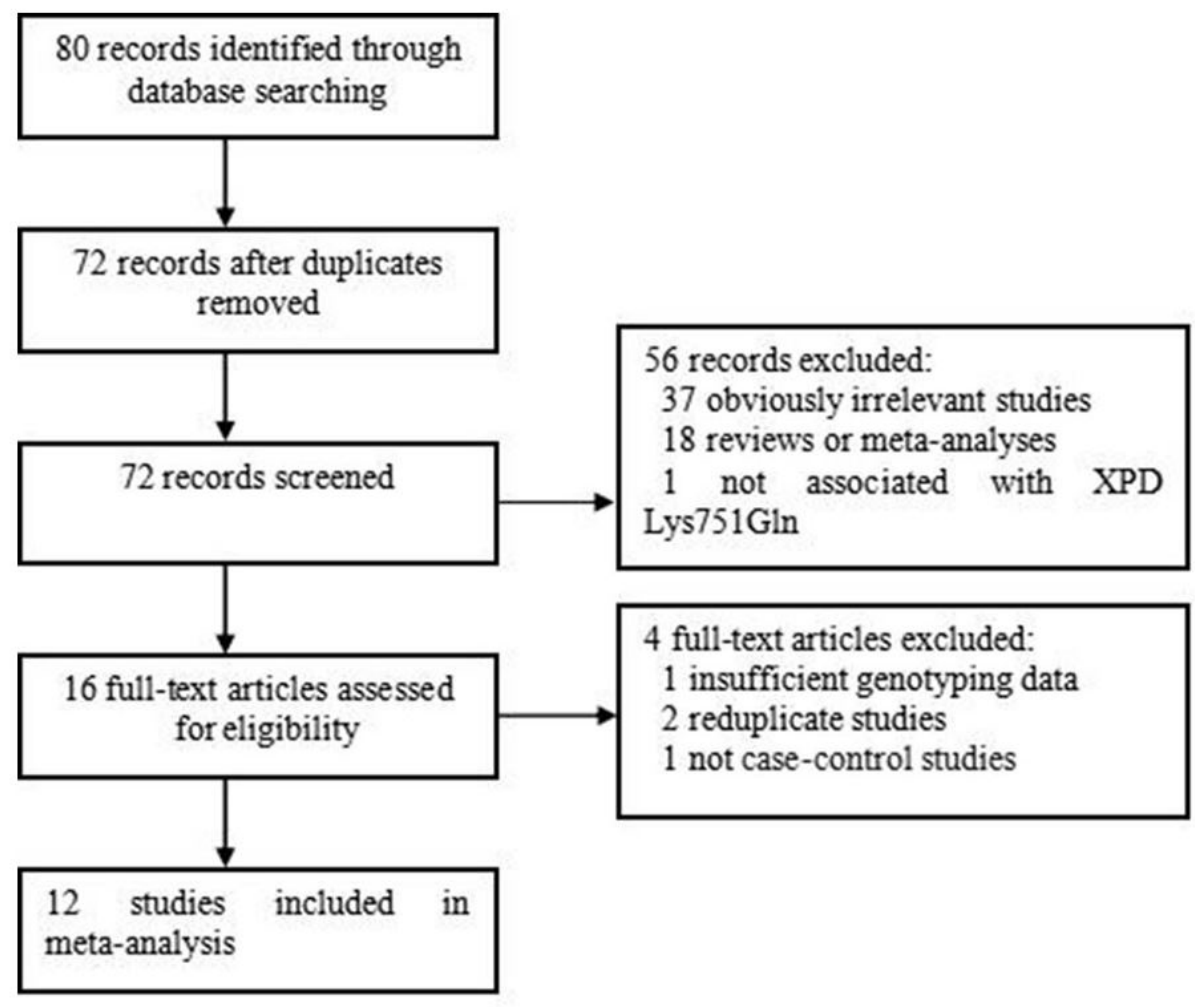

Figure 1. Flow diagram of the literature search. 
Table 1. Characteristics of studies included in the meta-analysis.

\begin{tabular}{|c|c|c|c|c|c|c|c|c|c|c|c|c|c|}
\hline \multirow{2}{*}{$\begin{array}{c}\text { Author and } \\
\text { publication year }\end{array}$} & \multirow{2}{*}{$\begin{array}{c}\text { Source } \\
\text { of } \\
\text { controls }\end{array}$} & \multirow{2}{*}{$\begin{array}{c}\text { Cancer } \\
\text { Type }\end{array}$} & \multirow{2}{*}{$\begin{array}{l}\text { Geographic } \\
\text { areas }\end{array}$} & \multirow{2}{*}{$\begin{array}{c}\text { Case } \\
\text { number }\end{array}$} & \multirow{2}{*}{$\begin{array}{l}\text { Control } \\
\text { number }\end{array}$} & \multicolumn{3}{|c|}{ Case } & \multicolumn{3}{|c|}{ Control } & \multicolumn{2}{|c|}{ HWE } \\
\hline & & & & & & $\begin{array}{l}\text { Lys/ } \\
\text { Lys }\end{array}$ & $\begin{array}{l}\text { Lys/ } \\
\text { Gln }\end{array}$ & $\begin{array}{l}\mathrm{Gln} / \\
\mathrm{Gln}\end{array}$ & $\begin{array}{l}\text { Lys/ } \\
\text { Lys }\end{array}$ & $\begin{array}{l}\text { Lys/ } \\
\text { Gln }\end{array}$ & $\begin{array}{c}\text { Gln/ } \\
\text { Gln }\end{array}$ & $\chi^{2}$ & $P$ \\
\hline Xing et al. (2002) & PB & ESCC & Beijing & 433 & 524 & 367 & 63 & 3 & 451 & 70 & 3 & 0.03 & 0.874 \\
\hline Yu et al. (2004) & $\mathrm{HB}$ & ESCC & Hubei & 135 & 152 & 108 & 16 & 11 & 133 & 17 & 2 & 2.58 & 0.108 \\
\hline Zhang et al. (2006) & $\mathrm{HB}$ & - & Jiangsu & 106 & 106 & 91 & 14 & 1 & 95 & 11 & 0 & 0.32 & 0.573 \\
\hline Zhou (2007) & $\mathrm{PB}$ & ESCC & Hebei & 327 & 612 & 274 & 51 & 2 & 522 & 86 & 4 & 0.05 & 0.824 \\
\hline Chen et al. (2008) & $\mathrm{PB}$ & ESCC & Jiangsu & 204 & 244 & 151 & 49 & 4 & 201 & 39 & 4 & 1.63 & 0.201 \\
\hline Zhai et al. (2009) & $\mathrm{HB}$ & ESCC & Henan & 200 & 200 & 167 & 31 & 2 & 148 & 51 & 1 & 2.39 & 0.122 \\
\hline Wu et al. (2012) & $\mathrm{PB}$ & ESCC & Henan & 235 & 235 & 136 & 86 & 13 & 142 & 79 & 14 & 0.46 & 0.499 \\
\hline Huang et al. (2012) & $\mathrm{HB}$ & ESCC & Xinjiang & 213 & 358 & 150 & 55 & 8 & 274 & 79 & 5 & 0.07 & 0.796 \\
\hline Wang (2012) & $\mathrm{PB}$ & ESCC & Henan & 415 & 415 & 264 & 125 & 26 & 289 & 110 & 16 & 1.78 & 0.182 \\
\hline Li \& Sun (2013) & $\mathrm{PB}$ & ESCC & Jiangsu & 400 & 400 & 283 & 105 & 12 & 321 & 73 & 6 & 0.61 & 0.434 \\
\hline Zhang et al. (2014) & $\mathrm{HB}$ & ESCC & Henan & 405 & 405 & 264 & 115 & 26 & 289 & 100 & 16 & 3.65 & 0.056 \\
\hline Zhu et al. (2015) & $\mathrm{HB}$ & ESCC & $\begin{array}{c}\text { Shanghai, } \\
\text { Jiangsu }\end{array}$ & 1122 & 1111 & 937 & 175 & 10 & 954 & 149 & 8 & 0.67 & 0.413 \\
\hline
\end{tabular}

PB, population-based; HB, hospital-based; ESCC, esophageal squamous cell carcinoma; HWE, Hardy-Weinberg equilibrium. $\chi^{2}$ is a test method and $P$ is $P$ value.

Table 2. Association of the XPD Lys751Gln polymorphism on esophageal cancer susceptibility.

\begin{tabular}{|c|c|c|c|c|c|}
\hline \multicolumn{2}{|c|}{ Analysis model } & $\mathrm{n}$ & $\mathrm{OR}_{\mathrm{r}}(95 \% \mathrm{CI})$ & $\mathrm{OR}_{\mathrm{f}}(95 \% \mathrm{CI})$ & $\mathrm{P}_{\mathrm{h}}$ \\
\hline \multirow[t]{5}{*}{ Gln vs. Lys } & Total analysis & 12 & $1.26(1.14-1.44)$ & $1.26(1.15-1.38)$ & 0.042 \\
\hline & $\mathrm{PB}$ & 6 & $1.28(1.11-1.47)$ & $1.28(1.13-1.45)$ & 0.296 \\
\hline & $\mathrm{HB}$ & 6 & $1.25(0.97-1.61)$ & $1.28(1.13-1.45)$ & 0.015 \\
\hline & North China & 7 & $1.15(0.98-1.36)$ & $1.18(1.05-1.32)$ & 0.085 \\
\hline & South China & 5 & $1.47(1.20-1.80)$ & $1.41(1.21-1.64)$ & 0.207 \\
\hline \multirow[t]{5}{*}{ Gln/Gln vs. Lys/Lys } & Total analysis & 12 & $1.69(1.25-2.27)$ & $1.73(1.29-2.31)$ & 0.751 \\
\hline & $\mathrm{PB}$ & 6 & $1.46(0.98-2.18)$ & $1.47(0.99-2.18)$ & 0.784 \\
\hline & HB & 6 & $2.02(1.29-3.15)$ & $2.10(1.35-3.25)$ & 0.547 \\
\hline & North China & 7 & $1.58(1.11-2.25)$ & $1.58(1.12-2.24)$ & 0.771 \\
\hline & South China & 5 & $1.98(1.13-3.47)$ & $2.12(1.23-3.63)$ & 0.425 \\
\hline \multirow[t]{5}{*}{ Gln/Gln vs. Lys/Lys + Asp/Asn } & Total analysis & 12 & $1.59(1.19-2.14)$ & $1.63(1.22-2.18)$ & 0.751 \\
\hline & $\mathrm{PB}$ & 6 & $1.37(0.92-2.03)$ & $1.37(0.93-2.03)$ & 0.820 \\
\hline & HB & 6 & $1.93(1.24-3.00)$ & $2.01(1.30-3.10)$ & 0.538 \\
\hline & North China & 7 & $1.50(1.06-2.12)$ & $1.50(1.06-2.12)$ & 0.779 \\
\hline & South China & 5 & $1.86(1.06-3.25)$ & $1.99(1.16-3.41)$ & 0.411 \\
\hline \multirow[t]{5}{*}{ Gln/Gln+ Asp/Asn vs. Lys/Lys } & Total analysis & 12 & $1.25(1.09-1.44)$ & $1.25(1.13-1.39)$ & 0.088 \\
\hline & PB & 6 & $1.31(1.13-1.52)$ & $1.31(1.13-1.51)$ & 0.367 \\
\hline & $\mathrm{HB}$ & 6 & $1.19(0.92-1.44)$ & $1.20(1.03-1.39)$ & 0.040 \\
\hline & North China & 7 & $1.14(0.95-1.37)$ & $1.16(1.02-1.33)$ & 0.091 \\
\hline & South China & 5 & $1.41(1.19-1.66)$ & $1.41(1.19-1.66)$ & 0.428 \\
\hline
\end{tabular}

ORr: Odd ratio for random-effects model; ORf: Odd ratio for fixed-effects model; $\mathrm{P}_{h}: P$ value for heterogeneity test.

\subsection{Meta-analysis results}

Evaluation of the associations about XPD Lys751Gln polymorphism on esophageal cancer risk was summarized in Table 2. Overall, we found a significantly increased risk of esophageal cancer in the entire analysis model (allele contrast, $\mathrm{OR}=1.26,95 \% \mathrm{CI}=1.14-1.44$; contrast of homozygotes, $\mathrm{OR}=1.73$, $95 \% \mathrm{CI}=1.29-2.31$; recessive model, $\mathrm{OR}=1.63,95 \% \mathrm{CI}=1.22-2.18$; dominant model, $\mathrm{OR}=1.25,95 \% \mathrm{CI}=1.13-1.39)$ (Table 2, Figure 2).

Subgroup analyses by geographic area and sources of control yielded consistent results with the overall finding in North China (allele contrast, $\mathrm{OR}=1.18,95 \% \mathrm{CI}=1.05-1.32$; contrast of homozygotes, $\mathrm{OR}=1.58,95 \% \mathrm{CI}=1.12-2.24$; recessive model, $\mathrm{OR}=1.50$,
95\%CI $=1.06-2.12$; dominant model, $\mathrm{OR}=1.16,95 \% \mathrm{CI}=1.02-1.33$ ) and South China (allele contrast, $\mathrm{OR}=1.41,95 \% \mathrm{CI}=1.21-1.64$; contrast of homozygotes, $\mathrm{OR}=2.12,95 \% \mathrm{CI}=1.23-3.63$; recessive model, $\mathrm{OR}=1.99,95 \% \mathrm{CI}=1.16-3.41$; dominant model, $\mathrm{OR}=1.41$, $95 \% \mathrm{CI}=1.19-1.66$ ); as well as in $\mathrm{PB}$ studies (allele contrast, $\mathrm{OR}=$ $1.28,95 \% \mathrm{CI}=1.13-1.45$; dominant model, $\mathrm{OR}=1.31,95 \% \mathrm{CI}=$ 1.13-1.51) and HB studies (contrast of homozygotes, $\mathrm{OR}=2.10$, $95 \% \mathrm{CI}=1.35-3.25$; recessive model, $\mathrm{OR}=2.01,95 \% \mathrm{CI}=1.30-3.10$ ).

\subsection{Sensitivity analysis and publication bias diagnosis}

Results from the sensitivity analyses suggested that the findings in the current meta-analysis were relatively stable (Table 2). 


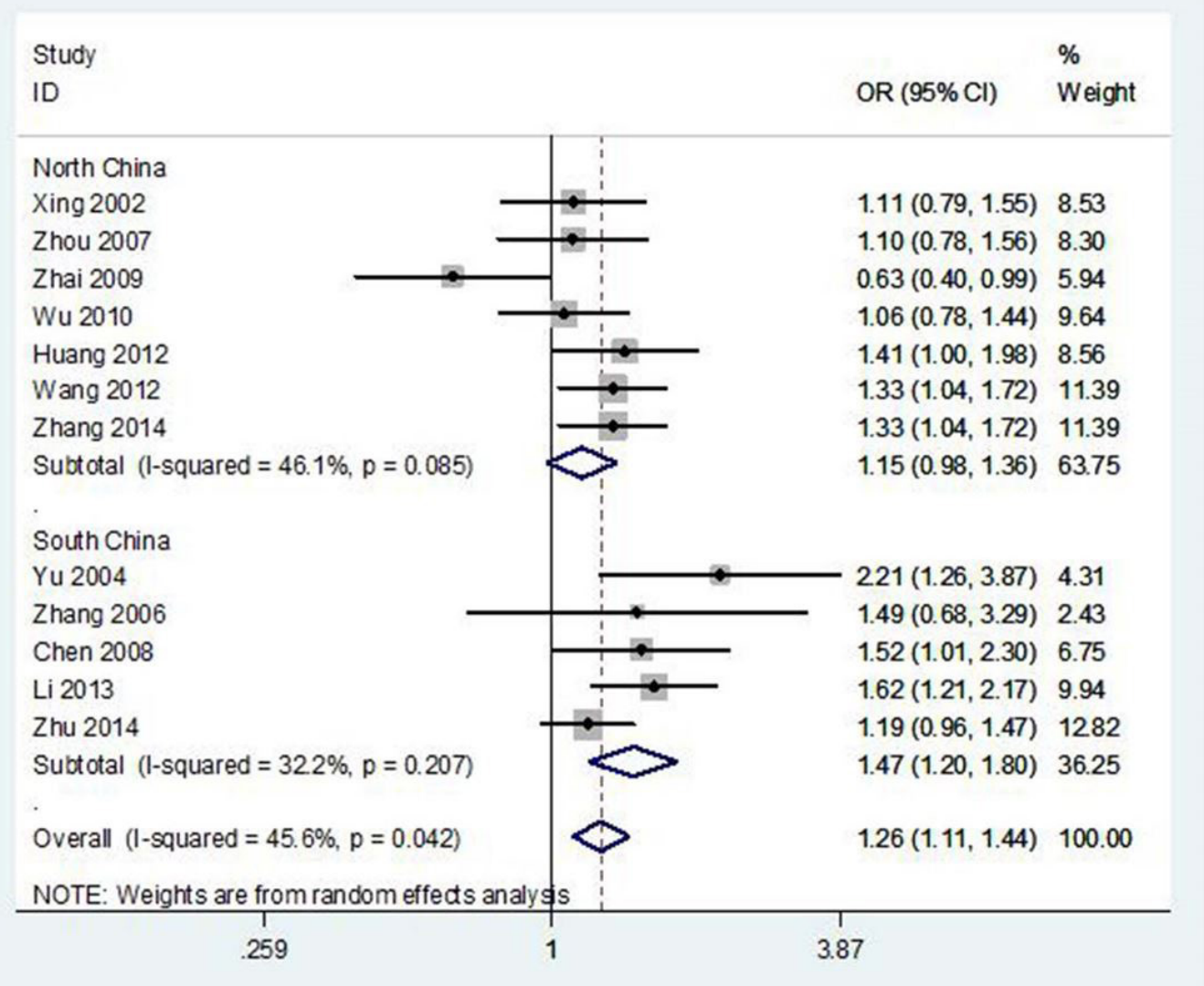

Figure 2. The forest plots on the association between XPD Lys751Gln polymorphism on esophageal cancer susceptibility under allele model.

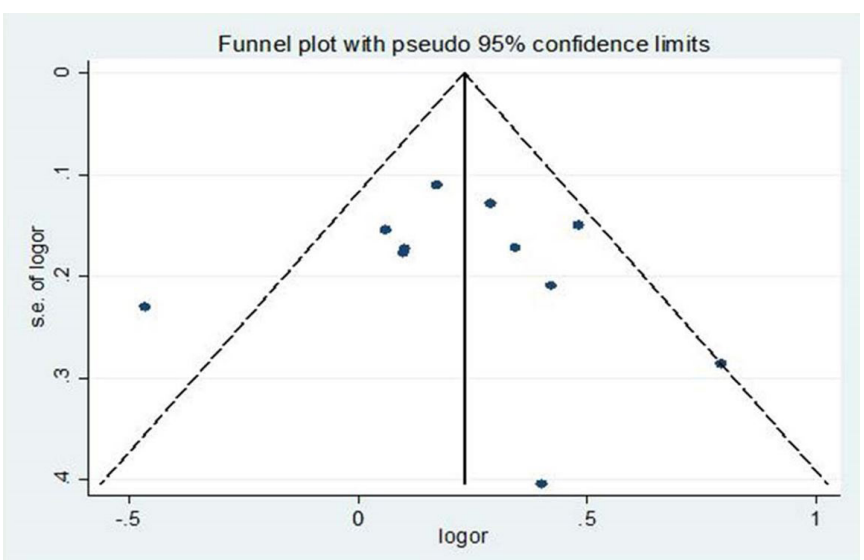

Figure 3. Publication bias assessment with Begg's funnel plot.

We did not detect any publication bias visually with funnel plot and Egger's test. In our test, funnel plot showed that the shape was symmetrical (Figure 3). Meanwhile, the Egger's test $(\mathrm{t}=0.19, p=0.850$, Figure 4$)$ was also not significant.

\section{Discussion}

The relation about XPD Lys751Gln polymorphism on esophageal cancer has been studied for many years, but there was no definite conclusion. So far, there are several meta-analyses which

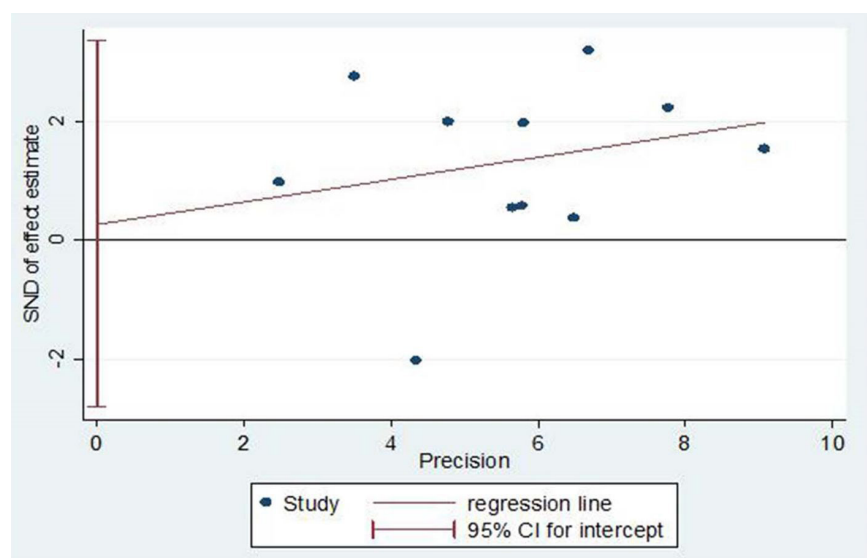

Figure 4. Egger's linear regression. SND: It stands for standard normal deviate.

were focused on XPD Lys751Gln polymorphism and esophageal cancer risk (Yuan et al., 2011; Ding et al., 2012; Yang et al., 2014; Guo et al., 2015). However, the conclusions from the published meta-analyses were still not consistent. Despite this, findings from the above mentioned studies are useful for this area and the future research directions (Yuan et al., 2011; Ding et al., 2012; Yang et al., 2014; Guo et al., 2015). The inconsistent results could be caused by the different regional and individual differences, as well as the small sample size included in every individual 
study. Subjects of different races may have unique cultures and lifestyles, which could affect the overall results. The present study was performed to assess the influence for Chinese only and then can decrease the effect of different geographic area background and lifestyle

Our meta-analysis used 12 articles comprising 4195 esophageal cancer cases and 4762 controls. The overall result suggested that XPD Lys751Gln polymorphism could increase the esophageal cancer risk in overall analyses. Hierarchical analysis was carried out to further investigate the differences of geographic location and source of controls while considering the effect of them. The significant relationship about XPD Lys751Gln polymorphism on esophageal cancer risk was also found both in North China and South China, as well as in PB studies and HB studies. We obtained consistent results with Ding et al. (2012), which suggested that significant relation between Lys751Gln genetic polymorphismand esophageal cancer among Chinese populations. However, it was inconsistent with Yuan et al.' (2011) study, which showed a non-significant relationship about XPD Lys751Gln polymorphism on esophageal cancer risk.

Several limitations were present in the current work. Firstly, we only searched and included the open published articles; however, some non-published literature which met our inclusion criteria may be missed. Secondly, the XPD gene was known as having more polymorphisms, not only containing Lys751Gln, but we focused our meta-analysis on the one most studied polymorphism because of the limited data in other polymorphisms. Third, esophageal cancer is a complex disease, which may be effect by both environmental and genetic factors. However, we cannot do the further analysis that may be affected by aging, cigarette smoking, alcohol consumption, and some other related environmental factors due to the limited data in the every included study.

\section{Conclusion}

In summary, the current meta-analysis of 12 studies indicated that XPD Lys751Gln polymorphism had a significant association on esophageal cancer risk in China. However, more studies with large sample sizes and detailed histological types of esophageal cancer in other populations are needed to confirm these findings.

\section{References}

Boer, J., \& Hoeijmakers, J. H. (2000). Nucleotide excision repair and human syndromes. Carcinogenesis, 21(3), 453-460. http://dx.doi. org/10.1093/carcin/21.3.453. PMid:10688865.

Chen, M. R., Wang, J. M., Guo, G. P., Hua, Z. L., Zhou, Q., \& Xu, B. (2008). Polymorphism of DNA repair gene XPD and XRCC land its relationship with esophageal squamous cell carcinoma. Fudan University Journal of Medical Science, 35, 273-281.

Ding, D. P., Ma, W. L., He, X. F., \& Zhang, Y. (2012). XPD Lys751Gln polymorphism and esophageal cancer susceptibility: a meta-analysis of case-control studies. Molecular Biology Reports, 39(3), 2533-2540. http://dx.doi.org/10.1007/s11033-011-1005-x. PMid:21667112.

Guo, X. F., Wang, J., Lei, X. F., Zeng, Y. P., \& Dong, W. G. (2015). XPD Lys751Gln polymorphisms and the risk of esophageal cancer: an updated meta-analysis. Internal Medicine, 54(3), 251-259. http:// dx.doi.org/10.2169/internalmedicine.54.3256. PMid:25748732.
Hoaglin, D. C. (2014). Assessment of heterogeneity in meta-analyses. Journal of the American Medical Association, 312(21), 2286-2287. http://dx.doi.org/10.1001/jama.2014.14346. PMid:25462001.

Hongo, M., Nagasaki, Y., \& Shoji, T. (2009). Epidemiology of esophageal cancer: Orient to Occident. Effects of chronology, geography and ethnicity. Journal of Gastroenterology and Hepatology, 24(5), 729-735. http://dx.doi.org/10.1111/j.1440-1746.2009.05824.x. PMid:19646015.

Huang, C. G., Liu, T., Lv, G. D., Liu, Q., Feng, J. G., \& Lu, X. M. (2012). Analysis of XPD genetic polymorphisms of esophageal squamous cell carcinoma in a population of Yili Prefecture, in Xinjiang, China. Molecular Biology Reports, 39(1), 709-714. http://dx.doi.org/10.1007/ s11033-011-0789-z. PMid:21553048.

Jemal, A., Bray, F., Center, M. M., Ferlay, F., Ward, E., \& Forman, D. (2011). Global cancer statistics. CA: a Cancer Journal for Clinicians, 61(2), 69-90. http://dx.doi.org/10.3322/caac.20107. PMid:21296855.

Li, R. Z., \& Sun, J. (2013). Association between XPD gene polymorphisms and esophageal quamous cell carcinoma. Molecular Medicine Reports, 7(2), 674-678. http://dx.doi.org/10.3892/mmr.2012.1215. PMid:23229387.

Liang, J. E. M., Wu, G., Zhao, L., Li, X., Xiu, X., Li, N., Chen, B., Hui, Z., Lv, J., Fang, H., Tang, Y., Bi, N., Wang, W., Zhai, Y., Li, T., Chen, D., Zou, S., Lu, N., Perez-Rodríguez, R., Zheng, J., \& Wang, L. (2013). Nimotuzumab combined with radiotherapy for esophageal cancer: preliminary study of a Phase II clinical trial. OncoTargets and Therapy, 6, 1589-1596. http://dx.doi.org/10.2147/OTT.S50945. PMid:24235844.

Moher, D., Liberati, A., Tetzlaff, J., \& Altman, D. G. (2009). Preferred reporting items for systematic reviews and meta-analyses: the PRISMA statement. PLoS Medicine, 6(7), e1000097. http://dx.doi. org/10.1371/journal.pmed.1000097. PMid:19621072.

Qiao, Y., Spitz, M. R., Shen, H., Guo, Z., Shete, S., Hedayati, M., Grossman, L., Mohrenweiser, H., \& Wei, Q. (2002). Modulation of repair of ultraviolet damage in the host-cell reactivation assay by polymorphic XPC and XPD/ERCC2 genotypes. Carcinogenesis, 23(2), 295-299. http://dx.doi.org/10.1093/carcin/23.2.295. PMid:11872635.

Sung, P., Bailly, V., Weber, C., Thompson, L. H., Prakash, L., \& Prakash, S. (1993). Human xeroderma pigmentosum group D gene encodes a DNA helicase. Nature, 365(6449), 852-855. http://dx.doi. org/10.1038/365852a0. PMid:8413672.

Vidal, A. R., Cansian, R. L., Mello, R. O., Kubota, E. H., Demiate, I. M., Zielinski, A. A. F., \& Dornelles, R. C. P. (2020). Effect of ultrasound on the functional and structural properties of hydrolysates of different bovine collagens. Food Sci. Technol, 40(2), 346-353. http://dx.doi. org/10.1590/fst.00319.

Wang, L. Z. (2012). Association of tagging SNPs in ERCC2 gene with esophageal squamous cell carcinoma in Henan Han population (Master thesis). Zhengzhou University, Zhengzhou.

Wu, X. B., Wang, P., Yun, Y. X., Wang, K., Wang, L. Z., Wang, K. J., Zhang, J. Y., \& Dai, L. P. (2012). Association of XPD gene polymorphisms with susceptibility of esophageal squamous cell carcinoma in Henan province. Chinese Journal of Public Health, 28, 446-449.

Xing, D., Qi, J., Miao, X., Lu, W., Tan, W., \& Lin, D. (2002). Polymorphisms of DNA repair genes XRCC1 and XPD and their associations with risk of esophageal squamous cell carcinoma in a Chinese population. International Journal of Cancer, 100(5), 600-605. http://dx.doi. org/10.1002/ijc.10528. PMid:12124811.

Yang, R., Zhang, C., Malik, A., Shen, Z. D., Hu, J., \& Wu, Y. H. (2014). Xeroderma pigmentosum group $\mathrm{D}$ polymorphisms and esophageal cancer susceptibility: a meta-analysis based on case-control studies. World Journal of Gastroenterology, 20(44), 16765-16773. http:// dx.doi.org/10.3748/wjg.v20.i44.16765. PMid:25469049. 
Yu, H. P., Wang, X. L., Sun, X., Su, Y. H., Wang, Y. J., Lu, B., Shi, L. Y., Xiong, C. L., Li, Y. Y., Li, F., \& Xu, S. Q. (2004). Polymorphisms in the DNA repair gene XPD and susceptibility to esophageal squamous cell carcinoma. Cancer Genetics and Cytogenetics, 154(1), 10-15. http:// dx.doi.org/10.1016/j.cancergencyto.2004.01.027. PMid:15381366.

Yuan, L., Cui, D., Zhao, E. J., Jia, C. Z., Wang, L. D., \& Lu, W. Q. (2011). XPD Lys751Gln polymorphism and esophageal cancer risk: a metaanalysis involving 2288 cases and 4096 controls. World Journal of Gastroenterology, 17(18), 2343-2348. http://dx.doi.org/10.3748/wjg. v17.i18.2343. PMid:21633601.

Zhai, X. D., Mo, Y. N., Xue, X. Q., Zhao, G. S., Gao, L. B., Ai, H. W., \& Ye, Y. (2009). XRCC1 codon 280 and ERCC2 codon 751 polymorphisms and risk of esophageal squamous cell carcinoma in a Chinese population. Bulletin du Cancer, 96(10), E61-E65. http:// dx.doi.org/10.1684/bdc.2009.0952. PMid:19762325.

Zhang, W. C., Yin, L. H., Pu, Y. P., Liu, R., Hu, X., Liu, Y. Z., \& Cui, Y. S. (2006). Relaionship between polymorphisms of DNA repair genes and esophageal cancer susceptibility. Chinese Journal of Public Health, 22, 557-558.

Zhang, Y., Wang, L., Wang, P., Song, C., Wang, K., Zhang, J., \& Dai, L. (2014). Association of single nucleotide polymorphisms in ERCC2 gene and their haplotypes with esophageal squamous cell carcinoma. Tumour Biology, 35(5), 4225-4231. http://dx.doi.org/10.1007/s13277013-1553-x. PMid:24390613.

Zhou, M. R. (2007). Correlation of nucleotide excision repair gene XPC and XPD polymorphisms to esophageal squamous cell carcinoma and gastric cardiac adenocarcinoma (Master thesis). Hebei University, Hebei.

Zhu, M. L., He, J., Wang, M., Sun, M. H., Jin, L., Wang, X., Yang, Y. J., Wang, J. C., Zheng, L., Xiang, J. Q., \& Wei, Q. Y. (2015). Potentially functional polymorphisms in the ERCC2 gene and risk of esophageal squamous cell carcinoma in Chinese populations. Scientific Reports, 4(1), 6281. http://dx.doi.org/10.1038/srep06281. PMid:25209371. 